\title{
Acrylamide reduces plasma antioxidant vitamin levels in rats due to increased oxidative damage
}

\author{
Acrilamida reduz os níveis de vitamina antioxidante \\ no plasma em ratos devido ao aumento \\ do dano oxidativo
}

Yeşim YENER' 1 (D) 0000-0002-3344-6637

Fatma Hümeyra YERLIKAYA2 (D) 0000-0002-4107-5389

\section{A B S T R A C T}

\section{Objective}

Acrylamide is a potentially neurotoxic and carcinogenic chemical and naturally creates during the heating process of carbohydrate-rich foods, such as potato chips and breakfast cereals. Acrylamide might be ingested by people via consuming food that contains it. Therefore, we investigated the effect of acrylamide given orally to male and female rats on plasma retinoic acid and a-tocopherol and serum sialic acid and malondialdehyde levels.

\section{Method}

A total of 50 Wistar rats were used (25 female and 25 male, three-four weeks old). The rats of each sex were given 2 and $5 \mathrm{mg} / \mathrm{kg} /$ day acrylamide via drinking water for 90 days. At the end of the treatment, the animals were euthanized by cervical dislocation. Blood specimens were collected through cardiac puncture, and serum and plasma samples were analysed using the high-performance liquid chromatography technique with a Ultraviolet detector.

\section{Results}

The analysis of the plasma and serum samples revealed that serum sialic acid and malondialdehyde levels in both sexes given $5 \mathrm{mg} / \mathrm{kg} /$ day acrylamide were significantly increased, and the serum sialic acid levels were

1 Bolu Abant İzzet Baysal University, Faculty of Education, Department of Elementary Education. Gölköy Campus, 14300, Bolu, Turkey. Correspondence to: Y YENER. E-mail: <yesimyener77@gmail.com>.

2 Necmettin Erbakan University, Meram Faculty of Medicine, Department of Biochemistry. Meram, Konya, Turkey.

\footnotetext{
How to cite this article
}

Yener Y, Yerlikaya FH. Acrylamide reduces plasma antioxidant vitamin levels in rats due to increased oxidative damage. Rev Nutr. 2020;33:e180232. http://dx.doi.org/10.1590/1678-9865202033e180232 
higher in female rats given $2 \mathrm{mg} / \mathrm{kg} /$ day acrylamide. The plasma retinoic acid and a-tocopherol levels significantly decreased in both sexes given only the highest dose.

\section{Conclusion}

The results show that acrylamide causes an increase in oxidative stress and leads to a decrease in the levels of retinoic acid and a-tocopherol which play a role in the defense mechanism against this stress.

Keywords: Acrylamide. Malondialdehyde. Retinoic acid. Sialic acid. a-tocopherol.

\section{R E S U M O}

\section{Objetivo}

A acrilamida é um químico potencialmente neurotóxico e carcinogênico, sendo naturalmente criada durante o processo de aquecimento de alimentos ricos em carboidratos, como batatas fritas e cereais matinais. Dado que o composto pode ser ingerido através do consumo de alimentos, o presente trabalho teve por objetivo investigar o seu efeito, quando administrado oralmente a ratos, medindo-se os níveis plasmáticos de ácido retinoico e a-tocoferol, bem como os níveis séricos de ácido siálico e malondialdeído

\section{Métodos}

Foram utilizados cinquenta ratos Wistar, sendo metade de cada sexo, com idade entre três e quatro semanas. Os animais foram divididos em dois grupos, os quais receberam diferentes doses diárias de acrilamida, via água potável, durante noventa dias: o primeiro ingeriu $2 \mathrm{mg} / \mathrm{kg} / \mathrm{dia}$; e o segundo, $5 \mathrm{mg} / \mathrm{kg} / \mathrm{dia}$. Ao final do tratamento, os animais foram eutanasiados por meio de luxação cervical. Amostras de sangue foram coletadas através de punção cardíaca, assim como amostras de soro e plasma foram medidas usando-se a técnica de cromatografia líquida de alta performance com detector de Ultravioleta.

\section{Resultados}

A análise das amostras de plasma e soro revelou que os níveis de ácido siálico e malondialdeído, em ratos de ambos os sexos tratados com acrilamida de $5 \mathrm{mg} / \mathrm{kg} / \mathrm{dia}$, foram significativamente aumentados, ao passo que os níveis séricos de ácido siálico foram maiores em ratas tratadas com $2 \mathrm{mg} / \mathrm{kg} / \mathrm{dia}$ de acrilamida. Já os níveis plasmáticos de ácido retinoico e a-tocoferol diminuíram significativamente em ratos de ambos os sexos, quando tratados com a dose mais elevada.

\section{Conclusão}

Os resultados mostram que a acrilamida causa um aumento no estresse oxidativo e leva a uma diminuição nos níveis de ácido retinoico e a-tocoferol, que desempenham um papel no mecanismo de defesa contra esse estresse.

Palavras-chave: Acrilamida. Malondialdeído. Ácido retinoíco. Ácido siálico. a-tocoferol.

\section{NTRODUCTION}

Acrylamide, a possible human carcinogen, has been shown to be generated in carbohydraterich foods during the heating process [1], and humans continuously receive a small amount of acrylamide via these foods $[2,3]$. In addition, contamination of food packaging material or water treatment and smoking are important sources of exposure to acrylamide [4]. Recent studies have shown that for human beings, the intake of acrylamide via food is approximately $0.31-1.1 \mu \mathrm{g} / \mathrm{kg}$ body weight/day [5-7]. The acrylamide exposure and its detrimental effects in children and adolescents are two times higher than that of adults due to their lower body weight and higher consumption of acrylamide-containing foods, such as crisps [7-9]. Acrylamide is easily absorbed by the intestinal cells and usually conjugates with glutathione. This conjugation leads to the reduction of cellular glutathione levels, which in turn increases reactive oxygen species inducing cellular damage [10]. 
Cells have glycoprotein layer on their surfaces and this layer has sialic acid at the end of the sugar chain. Glycoprotein has many significant roles in cells concerning immune response and cell-cell interaction. Sialic acid found in this layer is a useful marker of the acute response stage in several disorders. The elevated level of sialic acid indicates excessive cell membrane damage [11]. a-tocopherol, a type of vitamin $\mathrm{E}$, is an antioxidant that breaks the lipid peroxidation chain and deactivates free radicals by converting them to an oxidized product of a-tocopheroxyl free radical $[12,13]$. The formation of sufficient amount of a-tocopheroxyl in cells defends the body against oxidative stress. Retinoic acid, the acid corresponding to retinol, exists in both cis-trans isomeric forms, and is now considered a normal metabolite of vitamin A [14]. Vitamin A is required for growth and development ranging from organogenesis to metabolism and immunological wellness [15]. Recent findings indicate that reduction of retinoic acid can lower immunity while excess retinoic acid can induce inflammatory disturbances [16], Free radicals and reactive oxygen species formed during the metabolic processes of cells attack cellular components, such as proteins, deoxyribonucleic acid, and especially lipids. This causes oxidative degradation of lipids, and eventually leads to their peroxidation [17]. Malondialdehyde, a lipid peroxidation product, is frequently used as an indicator of cell membrane injury formed as a result of oxidative stress [18].

In the literature, there is only limited and inconclusive data concerning the oxidative status of plasma or serum in acrylamide exposure. These data are generally related to the acute and high dose effects of acrylamide. However, people are exposed to acrylamide chronically at low doses through intake of processed or contamined food. In addition, to our knowledge, the long-term low-dose effects of acrylamide on plasma retinoic acid, a-tocopherol and serum sialic acid levels in rats have not yet been examined. Therefore, in this study, we investigated these parameters in rats that received acrylamide.

\section{METHO D S}

Acrylamide was provided from Sigma and the chemical purity was $>99 \%$. Acrylamide solutions were prepared weekly dissolving in tap water and maintained at room temperature.

In this type of study, acrylamide must be given to rats either by gavage or in drinking water. However, the experimental period of our study was too long to give the substance by gavage without causing degeneration of oesophagus. Furthermore, considering the high water solubility of acrylamide $\left(2.16 \mathrm{~g} / \mathrm{mL}\right.$ at $\left.30^{\circ} \mathrm{C}\right)$, we chose to expose the rats to acrylamide via drinking water. We used 2 and $5 \mathrm{mg} / \mathrm{kg} /$ day doses to prevent acrylamide toxicity manifested as paralysis in the hind limb of animals [19].

Wistar rats of each sex, aged 3-4 weeks old, were obtained from Selcuk University Experimental Medicine Research and Application Centre (Konya, Turkey). The rats were kept at a controlled temperature and humidity $\left(20 \pm 2^{\circ} \mathrm{C}, 50 \%\right)$ in $12 \mathrm{~h} \mathrm{light/dark}$ cycle.

A total of 50 Wistar rats were used ( 25 female and 25 male). The body weights and birth times of the rats used for our study were comparable. Prior to the experiment, the rats were divided randomly and equally into five cages, five of each sex in each cage. During the 1 week acclimatization period, the average daily water consumption of rats in each cage was recorded and the amount consumed by each rat was calculated. Because the ages of the rats were the same and the body weights were comparable to within $5 \mathrm{~g}$, the slight differences among rats were ignored. We then calculated the amount of acrylamide to be given as $\mathrm{mg} / \mathrm{kg} /$ day and dissolved this amount in the 
volume of water they normally comsumed. In addition, dosages to be administered according to increasing water consumption every two weeks were adapted to take daily. The rats of each sex were divided into three groups as follows: Two groups (10 rats each) constituted the experimental groups that received 2 and $5 \mathrm{mg} / \mathrm{kg} /$ day acrylamide through drinking water for 90 days. The third group was the untreated control group that consisted of five rats, which were only given drinking water for 90 days. At the end of the treatment, the animals were euthanized using cervical dislocation. Blood specimens were collected through cardiac puncture. The serum and plasma were separated and kept at $-80^{\circ} \mathrm{C}$ until the time of analysis. All rats were fed with commercial food pellets, and drinking water was provided ad libitum throught the experiment.

The plasma retinoic acid and a-tocopherol levels were measured by a Chromsystems Indicator Kit (Munich, Germany) using high-performance liquid chromatography with a UV-detector.

The sialic acid levels were measured by a colorimetric assay developed by Warren [20]. Briefly, sialic acid was oxidized using sodium periodate in a strong acid solution. The resulting product was combined with thiobarbituric acid, and the chromophore obtained was separated into cyclohexanone.

Thiobarbituric acid-reactive substances were determined using the method described by Draper \& Hadley [21]. The principle of this method is based on the spectrophotometric measurement of the colour that occurs during the reaction between thiobarbituric acid and malondialdehyde. A portion of serum $(200 \mu \mathrm{L})$ was mixed with $2 \mathrm{~mL}$ of a solution containing $15 \%(\mathrm{w} / \mathrm{v})$ trichloroacetic acid, $0.38 \%(\mathrm{w} / \mathrm{v})$ thiobarbituric acid, and $0.25 \mathrm{~N}$ of hydrochloric acid. The mixture was heated at $100^{\circ} \mathrm{C}$ for 30 minutes, followed by centrifugation, and the absorbance was measured at $535 \mathrm{~nm}$.

The results of the experiment were assessed by the Statistical Package for the Social Sciences $\left(\mathrm{IBM}^{\circledR}, \mathrm{New}\right.$ York), and the significance was calculated using Tukey's multiple comparison tests. All the results are expressed as mean \pm Standard Deviations. The Internal Ethical Committee of Selcuk University approved the experimental animal procedure implemented in the study (No: 2011-095).

\section{R E S U L T S}

The analysis of the plasma retinoic acid and a-tocopherol, serum sialic acid and malondialdehyde levels in rats after acrylamide treatment did not reveal any symptoms of sickness or mortality. Table 1 and Figure 1 present the plasma retinoic acid and a-tocopherol, serum sialic acid and malondialdehyde levels in all groups. According to the results, the plasma retinoic acid and a-tocopherol levels of rats in both sexes given $5 \mathrm{mg} / \mathrm{kg} /$ day of acrylamide presented a statistically significant decrease $(p<0.05$ and $p<0.01$, respectively) compared to the rats given $2 \mathrm{mg} / \mathrm{kg} /$ day acrylamide and the control groups. However, there was no statistically significant difference between the groups depending on the dose (Table 1 and Figure 1).

When the serum sialic acid and malondialdehyde levels were examined in both sexes, it was found that the serum sialic acid levels showed a statistically significant increase in male rats given $5 \mathrm{mg} / \mathrm{kg}$ body weight/day acrylamide $(p<0.001)$ whereas in female rats, these levels presented a statistically significant increase in both dosage groups $(p<0.01)$. There was a statistically significant increase in the serum malondialdehyde levels of both sexes given just $5 \mathrm{mg} / \mathrm{kg}$ body weight/day acrylamide ( $p<0.05$ and $p<0.01$, respectively). However, no statistically significant difference was observed between the rats given $2 \mathrm{mg} / \mathrm{kg}$ body weight/day acrylamide and the control groups (Table 1 and Figure 1). 
Table 1. Plasma retinoic acid and a-tocopherol, serum sialic acid and malondialdehyde levels of all groups (mean \pm standard deviations).

\begin{tabular}{|c|c|c|c|c|c|c|c|c|}
\hline \multirow{2}{*}{ Parameters } & \multirow{2}{*}{ Groups } & \multicolumn{2}{|c|}{ Control } & \multicolumn{2}{|c|}{$2 \mathrm{mg}$ acrylamide $/ \mathrm{kg}$} & \multicolumn{2}{|c|}{$5 \mathrm{mg}$ acrylamide $/ \mathrm{kg}$} & \multirow{2}{*}{ Mean comparison $(p)$} \\
\hline & & M & SD & M & SD & M & SD & \\
\hline \multirow{2}{*}{$\begin{array}{l}\text { Retinoic acid } \\
(\mu \mathrm{mol} / \mathrm{L})\end{array}$} & Male & 1.19 & $( \pm 0.2)$ & 0.71 & $( \pm 0.3)$ & 0.47 & $\left( \pm 0.2^{c}\right)$ & \\
\hline & Female & 1.76 & $( \pm 0.4)$ & 1.28 & $( \pm 0.4)$ & 1.03 & $\left( \pm 0.1^{c}\right)$ & $<0.001$ \\
\hline \multirow{2}{*}{$\begin{array}{l}\text { a-tocopherol } \\
(\mu \mathrm{mol} / \mathrm{L})\end{array}$} & Male & 26.78 & $( \pm 3.5)$ & 25.95 & $( \pm 5.1)$ & 18.28 & $\left( \pm 3.3^{\mathbf{b}}\right)$ & \\
\hline & Female & 31.72 & $( \pm 7.2)$ & 28.15 & $( \pm 2.5)$ & 11.10 & $\left( \pm 1.9^{\mathrm{a}}\right)$ & $<0.001$ \\
\hline \multirow{2}{*}{$\begin{array}{l}\text { Sialic acid } \\
(\mathrm{mmol} / \mathrm{mL})\end{array}$} & Male & 6.64 & $( \pm 2.4)$ & 9.80 & $( \pm 4.5)$ & 18.18 & $\left( \pm 3.6^{\mathrm{a}}\right)$ & \\
\hline & Female & 8.86 & $( \pm 6.8)$ & 15.88 & $\left( \pm 3.9^{b}\right)$ & 18.28 & $\left( \pm 1.6^{\mathbf{b}}\right)$ & $<0.001$ \\
\hline \multirow{2}{*}{$\begin{array}{l}\text { Malondialdehyde } \\
(\mu \mathrm{mol} / \mathrm{L})\end{array}$} & Male & 7.43 & $( \pm 1.1)$ & 9.98 & $( \pm 1.0)$ & 11.27 & $\left( \pm 1.7^{c}\right)$ & \\
\hline & Female & 8.22 & $( \pm 1.6)$ & 11.54 & $( \pm 2.4)$ & 12.91 & $\left( \pm 2.8^{\mathbf{b}}\right)$ & $<0.01$ \\
\hline
\end{tabular}

Note: ${ }^{a} p<0.001,{ }^{b} p<0.01,{ }^{c} p<0.05$ statistically different compared to the control group.

M: Mean; SD: Standard Deviations.

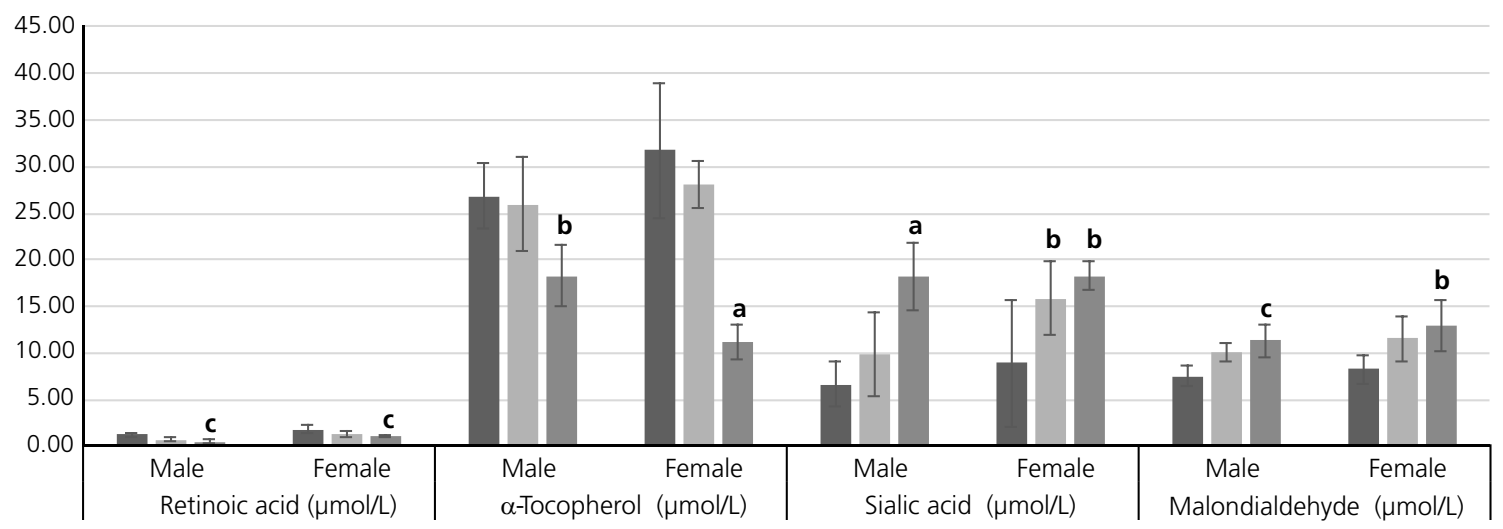

Control $\square 2 \mathrm{mg} / \mathrm{kg}$ AA $\square 5 \mathrm{mg} / \mathrm{kg} \mathrm{AA}$

Figure 1. Changes in the levels of plasma retinoic acid and a-tocopherol, serum sialic acid and malondialdehyde levels of male and female rats in all groups.

Note: ${ }^{a} p<0.001,{ }^{b} p<0.01,{ }^{c} p<0.05$ statistically different compared to the control group.

\section{DISCUSSION}

Sialic acid usually exists as a terminal constituent of carbohydrate chains in glycoproteins and glycolipids [22]. Lijima et al. [23] reported that monomeric sialic acid is a potential defence molecule against oxidative damage caused by hydrogen peroxide. Oxidative stress can cause the removal of the sialyl groups of glycoproteins of plasma proteins [24]. In the current study, the amount of serum sialic acid in rats after acrylamide treatment was higher than that of the control rats. This indicates that the removing of sialyl groups of glycoproteins in blood was increased with in the presence of acrylamide. In some studies, this was attributed to oxidative stress caused by acrylamide [25]. On the other hand, during inflammatory processes, the level of sialic acid in serum rises due to the increased high amount of sialylated glycoproteins $[26,27]$. Researchers have suggested a positive correlation between the level of sialic acid and c-reactive protein in serum $[28,29]$. In addition, the level of c-reactive protein increases in serum in case of response to inflammation. It has also been reported that food-based acrylamide intake may cause chronic inflammation [30,31]. Therefore, we concluded that acrylamide may lead to a proinflammatory state. 
When acrylamide enters the body by the oral route, it is metabolized in two ways; through conjugation with Glutathione (GSH) or through oxidation to glycidamide, an epoxide metabolite of acrylamide [32,33]. In the latter case, glycidamide may then conjugate with reduced GSH [32]. Yousef \& El-Demerdash [25] reported that acrylamide depleted GSH content in rats. The reduction of GSH to critical levels causes an increase in lipid peroxidation [34,35]. In the current study, it was observed that the levels of malondialdehyde, the yield of lipid peroxidation, were increased in the serum of the rats that received acrylamide. This may have resulted from the formation of reactive oxygen species due to the increased oxidative damage in these rats. In turn, increased ROS can lead to the oxidation of membrane lipids. Similar findings have been reported showing elevated serum malondialdehyde levels in rats after acrylamide treatment $[36,37]$.

Retinoic acid and a-tocopherol (non-enzymatic antioxidant defence system) directly detoxify free radicals [38]. We also observed a decrease in the levels of these parameters after acrylamide treatment. This decrease may have occurred due to the increased defence against oxidative stress caused by acrylamide. Our results consistent with previous reports that acrylamide decreased enzymatic antioxidant levels [36,39].

\section{CONCLUSION}

The results of the present study showed that acrylamide increases oxidative stress and causes cell membrane injury. This increased oxidative damage not only leads to the removal of the siayl groups of plasma proteins, but also leads to a decrease in the levels of retinoic acid and a-tocopherol that play a role in the defense mechanism against this damage.

\section{CONTRIBUTORS}

The design of the study, the application, and literature search were undertaken by all authors, and the article reviewed and the formatted by $Y$ Yener.

\section{REFERE NCES}

1. Stadler RH, Blank L, Vorga N, Robert F, Hav J, Guy, PA, et al. Acrylamide from Maillard reaction products. Nature. 2002;419(6906):449-50. http://dx.doi.org/10.1038/419449a

2. Tareke E, Rydberg P, Karlsson P. Analysis of acrylamide, a carcinogen formed in heated foodstuffs. J Agric Food Chem. 2000;50:4998-5006.

3. Virk-Baker MK, Nagy TR, Barnes S, Groopman J. Dietary acrylamide and human cancer: a systematic review of literature. Nutr Cancer. 2014;66:774-90.

4. El-Sayyad HI, El-Gammal HL, Habak LA, Abdel-Galil HM, Fernando A, Gaur RL, et al. Structural and ultrastructural evidence of neurotoxic effects of fried potato chips on rat postnatal development. Nutrition. 2011;27:1066-75.

5. Singh T, Kushwah AS. Acrylamide: a possible risk factor for cardiac health. Asian J Pharm Clin Res. 2018;11(10):39-48.

6. Pelucchi C, La VC, Bosetti C, Boyle P, Boffetta P. Exposure to acrylamide and human cancer: a review and meta-analysis of epidemiologic studies. Ann Oncol. 2011;7:1487-99.

7. European Food Safety Authority. Scientific opinion on acrylamide in food. EFSA J. 2015;13(6):4104.

8. Tran NL, Barraj LM, Collinge S. Reduction in dietary acrylamide exposure-impact of potatoes with low acrylamide potential. Risk Anal. 2017;37(9):1754-67. 
9. Kopp EK, Dekant W. Toxicokinetics of acrylamide in rats and humans following single oral administration of low doses. Toxicol Appl Pharmacol. 2009;235:135-42.

10. Ankaiah R, Kurrey NK, Krishnan MH. The positive intervention effects of resveratrol on acrylamide -induced cyto-/Genotoxicity in primary lymphocytes of rat. Phcog Mag. 2018;14:643-8.

11. Kumar D, RIzVI SI. Erythrocyte membrane bound and plasma sialic acid during aging. Biologia. 2013;68(4):762-5.

12. Tucker JM, Townsend DM. Alpha-tocopherol: roles in prevention and teraphy of human disease. Biomed Pharmacother. 2005;59:380-7.

13. Hajibabaei K. Antioxidant properties of vitamin E. Ann Res Antioxid. 2016;1(2):e22.

14. Cañete A, Cano E, Muñoz-Chápuli R, Carmona R. Role of vitamin A/retinoic acid in regulation of embryonic and adult hematopaiesis. Nutrients. 2017;9(2):159. http://dx.doi.org/10.3390/nu9020159

15. Guimarães IG, Lim C, Yildirim-Aksoy M, Li MH, Klesius PH. Effects of dietary levels of vitamin A on growth, hematology, immune response and resistance of Nile tilapia (Oreochromis niloticus) to Streptococcus iniae. Anim Feed Sci Thecnol. 2014;188:126-36.

16. Hall JA, Grainger JR, Spencer SP, Belkaid Y. The role of retinoic acid in tolerance and immunity. Immunity. 2011;35:13-22.

17. Grotto D, Maria LS, Valentini J. Importance of the lipid peroxidation biomarkers and methodological aspects for malondialdehyde quantification. Quim Nova. 2009;32:169-74.

18. Khoubnasabjafari M, Ansarin K, Jouyban A. Reliability of malondialdehyde as a biomarker of oxidative stress in psychological disorders. Bioimpacts. 2015;5:123-7.

19. Burek JD, Albee RR, Beyer JE, Bell TJ, Carreon RM, Morden DC, et al. Subchronic toxicity of acrylamide administered to rats in drinking water follewed by up to 144 days of recovery. J Environ Pathol Toxicol. 1980;4:157-82.

20. Warren L. The thiobarbituric acid assay of sialic acid. J Biol Chem. 1959;234:1971-5.

21. Draper HH, Hadley M. Malondialdehyde determination as index of lipid peroxidation. Methods Enzymol. 1990;186:421-31.

22. Schnaar RL, Gerardy-Schahn R, Hildebrandt H. Sialic acid in the brain: gangliosides and polysialic acid in nervous system development, stability, disease, and regeneration. Physiol Rev. 2014;94:461-18.

23. Lijima R, Takahashi H, Namme R, Ikegami S, Yamazaki M. Novel biological function of sialic acid (N-acetylneuraminic acid) as a hydrogen peroxide scavenger. Febs Lett. 2004;561:163-6.

24. Rajendiran S, Lakshamanappa HS, Zachariah B, Nambiar S. Desialylation of plasma proteins in severe dengue infection possible role of oxidative stres. Am J Trop Med Hyg. 2008;79:372-7.

25. Yousef MI, El-Demerdash FM. Acrylamide-induced oxidative stres and biochemical perturbation in rats. Toxicol. 2006;219:133-41.

26. Yılmaz FM, Yılmaz G, Savaş Erdeye S, Dallar Y, Topkaya BC, et al. Serum sialic acid, hs-CRP and oxidetive stres parameters in obese children. J Pediatr Endocrinol Metab. 2007;20:205-10.

27. Mohan SK, Priyav V. Serum total sialic acid, lipid peroxidation, and glutathione reductase levels in patients with rheumatoid arthritis. Turk J Med Sci. 2010;40:537-40.

28. Ovist R, Ismail IS, Muniandy S, Vellasamy KM, Chinn K. Correlation of plasma C-reactive protein levels to sialic acid and lipid concentrations in the normal population. J Med Sci. 2007;7:1049-53.

29. Bajendiran KS, Ananthanarayanan RH, Satheesh S, Rajappa M. Elevated levels of serum sialic acid and highsensitivity C-reactive protein: markers of systematic inflammation in patients with chronic heart failure. $\mathrm{Br} J$ Biomed Sci. 2014;71:29-32.

30. Naruszewicz M, Zapolska-Downar D, Kośmider A, Nowicka G, Kozlowska-Wojciechowska M, Vikström AS, et al. Chronic intake of potato chips in humans increases the production of reactive oxygen radicals by leucocytes and increases plasma C-reactive protein: a plot study. Am J Clin Nutr. 2009;89(6):1951. http:// dx.doi.org/10.3945/ajen.2008.26647

31. Lyn-Cook LE, Tareke E, Word B, Starlard-Davenport A, Lyn-Cook BD, Hammons GJ. Food contaminant acrylamide increases inflammation in breast cells. Toxicol Ind Health. 2011;27:11-8.

32. Luo YS, Long TY, Shen LC, Huang SL, Chiang SY, Wu KY. Synthesis, characterization and analysis of the acrylamide- and glycidamide-glutathione conjugates. Chem Biol Interact. 2015;237:38-46. http://dx.doi. org/10.1016/j.cbi.2015.05.002 
33. Li D, Wang P, Liu Y, Hu X, Chen F. Metabolism of acrylamide: interindividual and interspecies differences as well as the application as biomarkers. Curr Drug Metab. 2016;17:317-26.

34. Srivastava SP, Daş M, Seth PK. Enhancement of lipid peroxidation in rat liver on acut exposure to styrene and acrylamide a concequence of glutathione depletion. Chem Biol Interact. 1983;45:373-80.

35. Radu M, Munteanu MC, Petrashe S, Serban Al, Dinu D, Hermanean A, et al. Depletion of intracellular glutathione and increased lipid peroxidation mediate cytotoxicity of hematite nanoparticles in MRC-5 cells. Acta Biochem Pol. 2010;57:355-60.

36. Catalgol B, Ozhan G, Alpertunga B. Acrylamide-induced oxidative stres in human erythrocytes. Hum Exp Toxicol. 2009;28(10):611-7. http://dx.doi.org/10.1177/0960327109350664

37. Pan X, Wu X, Yan D, Peng C, Rao C, Yan H. Acrylamide-induced oxidative stress and inflammatory response are alleviated by N-acetylcysteine in PC12 cells: involvement of the crosstalk between Nrf2 and NF-kB pathways regulated by MAPKs. Toxicol Lett. 2018;288:56-64.

38. Birben E, Sahiner UM, Sackesen C, Erzurum S, Kalaycı O. Oxidative stress and antioxidant defence. World Allergy Organ J. 2012;5:9-19.

39. Sridevi B, Reddy KV, Reddy SL. Effect of trivalent and hexavalent chromium on antioxidant enzyme activities and lipid peroxidation in a freshwater field crab, Barytelphusa guerini. Bull Environ Contam Toxicol. 1998;61:389-90. 